\title{
Analyses of Aerosol Events Observed at Four Sun Photometer Sites in Japan during March-April 2002
}

\author{
Yukitomo TSUTSUMI, Hideaki MORISHITA ${ }^{1}$, Masashi YOSHIDA \\ Atmospheric Environment Division, Japan Meteorological Agency, Tokyo, Japan \\ Kouichi ODASHIMA, Atsushi SAITO² \\ Atmospheric Environment Observatory, Japan Meteorological Agency, Tokyo, Japan \\ Kenji SUZUKI \\ Yonagunijima Weather Station, Japan Meteorological Agency, Tokyo, Japan \\ and \\ Osamu IJIMA \\ Aerological Observatory, Japan Meteorological Agency, Tokyo, Japan \\ (Manuscript received 22 November 2002, in final form 21 April 2004)
}

\begin{abstract}
Aerosol-induced atmospheric optical phenomena were analyzed at four sun photometer sites in Japan, viz., Ryori $\left(39^{\circ} 02^{\prime} \mathrm{N}, 141^{\circ} 50^{\prime} \mathrm{E}\right)$, Tsukuba $\left(36^{\circ} 03^{\prime} \mathrm{N}, 140^{\circ} 08^{\prime} \mathrm{E}\right)$, Yonagunijima $\left(24^{\circ} 28^{\prime} \mathrm{N}, 123^{\circ} 01^{\prime} \mathrm{E}\right)$, and Minamitorishima $\left(24^{\circ} 18^{\prime} \mathrm{N}, 153^{\circ} 58^{\prime} \mathrm{E}\right)$, over the period March-April 2002 to elucidate the causes of such phenomena, and explain regional differences. Using observed optical properties, the phenomena were classified into three kinds of aerosol events: Type A, Type B, and Type C, which, respectively, correspond to relatively clear conditions, typical Kosa conditions, and haze conditions. The frequency of occurrence of these aerosol events was found to be significantly different at the four observation sites in Japan during the observation period. Type B events were found to occur rather frequently in Ryori in northern Japan. The severe Kosa events observed at Ryori on April 10, 2002, which constitute a case study, passed over Northeast China where dust storms have rarely been reported before 2000. The smallest mean aerosol optical depth at $500 \mathrm{~nm}\left(\tau_{500}\right)$ and Ångström exponent $(\alpha)$ were observed in Minamitorishima. However, according to other studies, the mean $\tau_{500}$ in Minamitorishima was larger than those in the eastern Pacific, which showed that the influence of the Asian outflow on atmospheric optical
\end{abstract}

Corresponding author: Yukitomo Tsutsumi, Atmospheric Environment division, Japan Meteorological Agency, 1-3-4 Otemachi, Tokyo 100-8122, Japan.

E-mail: y-tsutsumi@met.kishou.go.jp

1 Present affiliation: Administration Division, Climate and Marine Department, Japan Meteorological Agency

2 Present affiliation: Aerological Observatory, Japan Meteorological Agency

(C) 2004, Meteorological Society of Japan 
properties was still significant even $3,000 \mathrm{~km}$ away from the Asian continent. The mean $\tau_{500}$ and $\alpha$, as well as the frequency of occurrence of Type $\mathrm{C}$ events, were the largest at our observation site in Yonagunijima. Based on the trajectory analysis obtained during the observation period, the high frequency of Type C events at Yonagunijima was ascribed to the haze from biomass burning in Southeast Asia and/or urban pollution in coastal areas in Southeast China. The frequency of Type C events in Ryori and Tsukuba indicated that haze is not an uncommon occurrence, not only in southern Japan, but also in central and northern Japan, and that, along with Kosa events, they may affect atmospheric optical properties over Japan in the spring.

\section{Introduction}

Large atmospheric turbidity is occasionally observed in the western Pacific. Various aerosols influence the atmospheric optical properties in this region, most notably: Kosa particles (aeolian mineral dust) in East Asia, aerosols formed from anthropogenic-gas emissions in East Asia, and smoke particles from biomass burning in Southeast Asia and Siberia.

"Kosa" is mineral dust particles in East Asia. Owing to its color, it is also referred to as "yellow sand" in some cases. A Kosa event is an aeolian dust phenomenon observed in East Asia, and is known to occur frequently in the spring (Kurosaki and Mikami 2002). The main source regions are the Taklamakan Desert, the Gobi Desert, and the Loess Plateau (Kai et al. 1998; Kurosaki and Mikami 2003). The stirred up dust is usually transported over East Asia, or the western Pacific, by westerlies. A portion of the Kosa particles were carried over the $\mathrm{Pa}$ cific (Uno et al. 2001; Husar et al. 2001), and detected in the west coast of America and Canada (e.g., Jaffe et al. 1999; McKendry et al. 2001).

The aeolian dust experiment on climate impact (ADEC) project started in April 2000 in collaboration with China, to study the influence of Kosa on the atmosphere (Mikami et al. 2002). During an intensive observation period in Spring 2002, many groups in the ADEC project made simultaneous measurements on Kosa. Through the sunphotometry network with 3 observation sites in Japan, the Atmospheric Environment Division (AED), within the Japan Meteorological Agency (JMA), has observed aerosol optical depths at five wavelengths $(368,500,675,778,862 \mathrm{~nm})$ three times a day as a part of the Global Atmosphere Watch in the World Meteorological Organization (Japan Meteorological Agency 2003). AED/
JMA joined the ADEC project, and also made intensive measurements on an hourly-mean basis from March through April 2002 at the three JMA sun photometer sites and the Aerological Observatory in Tsukuba.

In East Asia, not only Kosa particles, but also anthropogenic aerosols emitted from urban areas, and smoke particles emitted from biomass burning, have an important effect on atmospheric optical properties. The Asian outflow, with urban pollution, significantly influences atmospheric chemistry including aerosols in the western Pacific (Xiao et al. 1997; Gregory et al. 1997; Talbot et al. 1997). Takemura et al. (2002; 2003) have shown that the contribution of pollution-induced aerosols to the total optical depth is simulated to be comparable to that of the Kosa dust. Biomass burning, on the other hand, is known to be frequent in tropical Southeast Asia (Liu et al. 1999; Chan et al. 2003), but has been recognized to occur in recent years, even in boreal forests in Siberia and the Russian Far East (Tanimoto et al. 2000; Wotawa et al. 2001; Kajii et al. 2002; Kasischke and Bruhwiler 2003). Aoki and Fujiyoshi (2003) observed small particles $(\sim 0.2 \mu \mathrm{m})$, with a large aerosol optical depth, at Sapporo in northern Japan in August 1998. They pointed out that Siberian forest fires caused the increase in aerosol optical depth.

The above studies suggest that many kinds of aerosols affect atmospheric optical properties over Japan. Moreover, they can affect not only the climate through offsetting, or acceleration of global warming, but also ordinary daily life, such as the effect of poor visibility on transportation. Thus, atmospheric phenomena, with significant optical properties, are well worth researching. There are several observational studies focused on particular Kosa events in Japan (e.g., Arao and Ishizuka 1986; Tanaka et al. 1989; Murayama et al. 2001; Suzuki et 


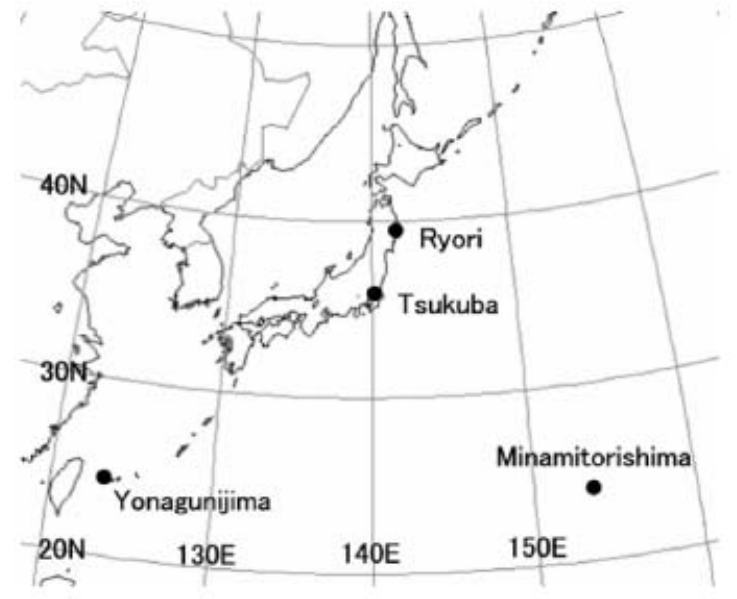

Fig. 1. The JMA sun photometer sites (closed circle).

al. 2001), but comprehensive analyses on atmospheric optical phenomena, including aerosols from various emissions, are limited. Aoki and Fujiyoshi (2003) presented monitoring results of aerosol optical properties over a period of several years, and indicated, for example, the spring maximum and autumn minimum of aerosol optical depth in Sapporo. However, their observation sites covered only the central and northern parts of Japan.

The present paper focuses on aerosol events with significant optical properties, induced not only by Kosa, but also by other kinds of aerosol, and aims to elucidate the causes of aerosol events, and to explain the regional differences during March-April 2002.

\section{Experiment}

The observation sites of the sunphotometry network during the ADEC project were Ryori $\left(39^{\circ} 02^{\prime} \mathrm{N}, \quad 141^{\circ} 50^{\prime} \mathrm{E}\right), \quad$ Tsukuba $\left(36^{\circ} 03^{\prime} \mathrm{N}\right.$, $\left.140^{\circ} 08^{\prime} \mathrm{E}\right)$, Yonagunijima $\left(24^{\circ} 28^{\prime} \mathrm{N}, 123^{\circ} 01^{\prime} \mathrm{E}\right)$, and Minamitorishima $\left(24^{\circ} 18^{\prime} \mathrm{N}, 153^{\circ} 58^{\prime} \mathrm{E}\right)$ (Fig. 1). Ryori is located near the coast in northern Japan; Tsukuba is situated in the Kanto Plain in central Japan; Yonagunijima is a small southwestern island, close to the Asian continent; and Minamitorishima is a remote island in the central-western Pacific. The sun photometers used were MS-110 (EKO Instruments Trading Co. Ltd.). The observed wavelengths were $368,500,675,778$, and $862 \mathrm{~nm}$.
Aerosol optical depth $\tau(\lambda)$ is generally defined as $\tau(\lambda)=1 / m \cdot \ln \left\{J_{0}(\lambda) /\left(J(\lambda) \cdot\left(R / R_{0}\right)^{2}\right)\right\}-$ $\tau_{R}(\lambda)-\tau_{O 3}(\lambda)$, where $\lambda$ is the observed wavelength, $m$ is the relative air mass, $J_{0}$ is an instrument constant, $J$ is the output from a sun photometer, $R$ is the sun-earth distance on the observation time, $R_{0}$ is the mean sun-earth distance, $\tau_{R}(\lambda)$ is the Rayleigh scattering optical depth, and $\tau_{O 3}(\lambda)$ is the ozone optical depth. The $\tau(\lambda)$ is derived by the same method in Suzuki et al. (2001), but using standard pressure. All instruments used at the observation sites were calibrated by the Langley method at Komagane (2612 $\mathrm{m}$ above sea level) in Nagano prefecture in November 2001-all $J_{0}$ values used in the observations were determined by this calibration.

This analysis was made for the optical depth acquired from March 1, 2002 to April 30, 2002 on a minute-by-minute basis. In general, clouds between a sun photometer and the sun affect observation of aerosol optical depth, so that data influenced by clouds needs to be excluded. To determine an adequate threshold for excluding cloud-affected data, three-, seven- and 15-minute running means were examined with a standard deviation threshold of less than 0.03 every 0.01 bin in Ryori on April 10, 2002, when a large scale Kosa event occurred in the northern part of Japan. The use of an optical depth, whose 7-minute running-mean standard deviation was less than 0.03 , could exclude the cloud effect while still preserving the Kosa effect. Thus, the present paper employs this optical depth as the aerosol optical depth. The Angström exponent, which represents the wavelength dependence of aerosol optical depth, and an index of particle size distribution, was also derived from a multi-spectral log-linear fit of the aerosol optical depths, to the equation $\tau(\lambda) \propto \lambda^{-\alpha}$, where $\alpha$ is the Ångström exponent (Ångström 1961).

If the number of employed aerosol optical depth exceeded nine within an hour, the hourly mean aerosol optical depth and Ångström exponent $(\alpha)$ were averaged with the data employed. In this paper, the aerosol optical depth at a wavelength of $500 \mathrm{~nm}\left(\tau_{500}\right)$ and $\alpha$ based on this hourly mean data are discussed.

The 7-day backward trajectories of air masses along isentropic surfaces were calculated to estimate the origin of the observed air 
mass, using objective analysis data (GANAL) provided by the JMA. The model used was the same as that used by the JMA (2003).

The weather characteristics during the observation period were unusually high temperatures in eastern China, and an eastward wind-vector anomaly at $850 \mathrm{hPa}$, which was more than $4 \mathrm{~m} / \mathrm{s}$ stronger than normal, from Korea to the northern part of Japan $\left(>35^{\circ} \mathrm{N}\right)$ in March 2002 (Japan Meteorological Agency 2002a). The weather in April 2002 was almost normal around East Asia (Japan Meteorological Agency 2002b).

\section{Results and discussion}

\subsection{Classification of aerosol events using observed aerosol optical properties}

The JMA meteorological observation network, with 123 stations in Japan, monitors the occurrence of Kosa events on a daily basis with a range of visibilities. Since a Kosa event usually occurs on a synoptic scale, an observation network will need to have a $200 \sim 300 \mathrm{~km}$ resolution for capturing the distribution. Thus, any day when any JMA meteorological station within $200 \mathrm{~km}$ of a sun photometer site reported a Kosa event was termed a "Kosa event day". It should be noted, however, that the term only refers to days with significant Kosa occurrences in the lower atmospheric layers, because Kosa observation does not always detect Kosa dust transported in higher altitudes, which can influence sun photometer readings.

Minamitorishima is located more than $3,000 \mathrm{~km}$ away from any continent. Thus, it can be assumed that a significant dust or haze event rarely occurs in Minamitorishima due to subsidence or diffusion. Figure 2 shows the frequency of occurrence distributions for hourlymean $\tau_{500}$ at the sun photometer sites during March-April 2002, in a similar method to Holben et al. (2001) and Smirnov et al. (2002). As can be seen in Fig. 2, $\tau_{500}$ exceeded 0.3 with a frequency of only $1.2 \%$ in Minamitorishima. Thus, an atmospheric optical phenomenon with $\tau_{500}>0.3$ at all observation sites was defined as a significant aerosol event. Figure 3 plots the a versus $\tau_{500}$ at sun photometer sites during March-April 2002. As seen in the figure, $\tau_{500}$ seldom falls below 0.3 during a "Kosa event day", justifying our definition of a significant aerosol event $\left(\tau_{500}>0.3\right)$. Figure 4 is the fre-

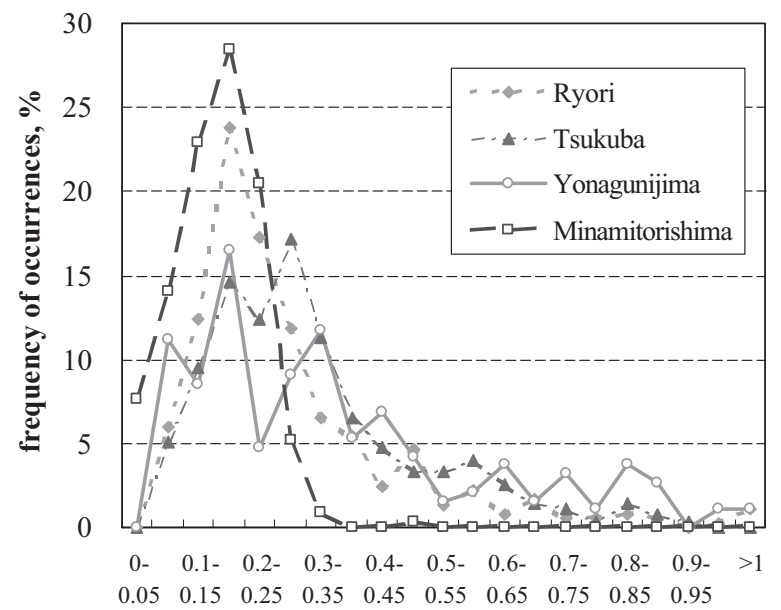

aerosol optical depth

Fig. 2. Frequency of occurrence distributions for hourly mean aerosol optical depth at Ryori (closed diamond), Tsukuba (closed triangle), Yonagunijima (open circle), and Minamitorishima (open rectangle) during March-April 2002. Aerosol optical depth is plotted every 0.05 bin.

quency of occurrence distribution of hourly average $\alpha$ at $\tau_{500}>0.3$ obtained during the observation period. The frequency distributions in the figure suggest a superimposition of two dominant aerosol sizes over Japan. The boundary of $\alpha$, between the two peaks, is clearly located around $a=1.0$.

Thus, based on optical properties, atmospheric optical phenomena are classified into the following three kinds of aerosol events: Type A if $\tau_{500}=0.3$; Type B if $\tau_{500}>0.3$ and $a=1.0$; Type $\mathrm{C}$ if $\tau_{500}>0.3$ and $a>1.0$ (see Fig. 3(a)). Type A events are defined by a relatively clear background condition. Tanaka et al. (1989), and Suzuki et al. (2001), observed that $\tau_{500}$ ranged between 0.4 and 0.6 , and a was less than 0.5 during typical Kosa events. Thus, Type $B$ data mainly include typical Kosa events. It should, however, be noted that Type B events do not necessarily include all Kosa conditions, because a weak but steady transport of Kosa dust in the free troposphere (Iwasaka et al. 1988; Matsuki et al. 2002; Matsuki et al. 2003), may occur during the observation period. Eck et al. (1999) and Aoki and Fujiyoshi (2003) observed a values in the range 1.7-2.0 in the case 

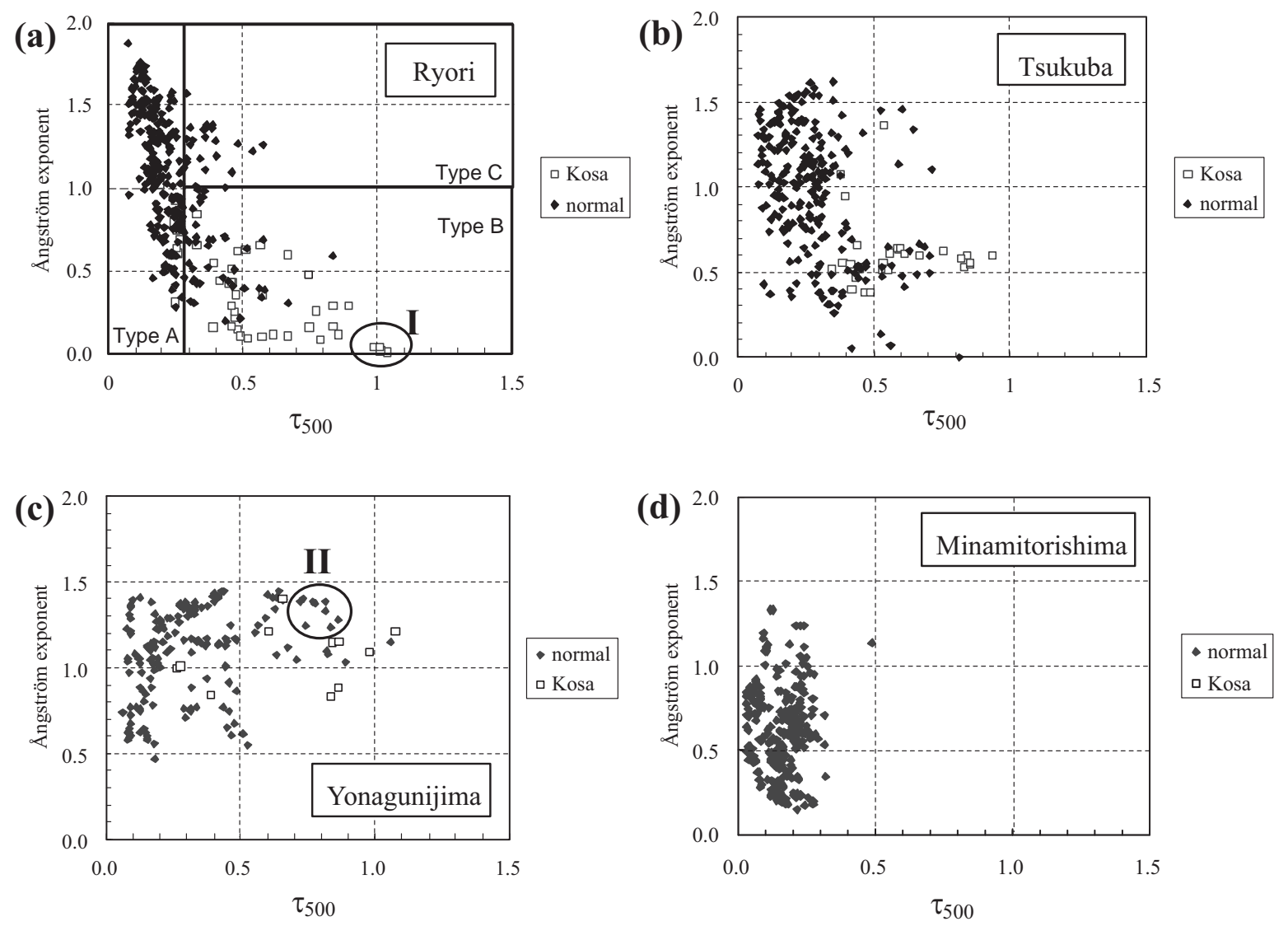

Fig. 3. Scatter plots of Ångström exponent $(\alpha)$ versus an aerosol optical depth of $500 \mathrm{~nm}\left(\tau_{500}\right)$ at Ryori (a), Tsukuba (b), Yonagunijima (c), and Minamitorishima (d) during March-April 2002. All data are hourly means. Open rectangles are data obtained during "Kosa event days". An example of the type classification is illustrated for Ryori. The data group labeled "I" are from observations at Ryori on April 10, 2002. The data group labeled "II" are from observations at Yonagunijima on April 7-8, 2002.

of air mass from forest fires. Moulin et al. (1997) reported an $\alpha$ value of about 1.5 during anthropogenic pollution events. These studies showed that haze originating from biomass burning, or urban pollution, has a large $\alpha$ (>1.0). Thus, haze events constitute the main part of Type $\mathrm{C}$ data.

\subsection{Ryori and Tsukuba}

Table 1 and Fig. 5 show the mean $\tau_{500}$ and $\alpha$ with standard deviations, as recorded by the observation sites during the observation period. In Ryori and Tsukuba, mean values ranged from 0.28 to 0.31 for $\tau_{500}$, and from 0.94 to 0.99 for $\alpha$. Furthermore, as illustrated in Fig. 6, the frequency of Type B occurrence in Ryori
(23\%) in northern Japan was roughly comparable to that in Tsukuba (31\%) in central Japan. As pointed out by Aoki and Fujiyoshi (2003), studies on Asian dust events in northern Japan are limited, but they indicate that Asian dust particles affected the aerosol concentration and size distribution during the spring in Sapporo (northern Japan). Our results not only support their conclusion, but also suggest that the frequency of occurrence of typical Kosa events in northern Japan in the spring is not so low. While the anomalous weather conditions during March 2002, described in Section 2, might be linked to the frequency of Type B events in Ryori, further analyses based on annual variations will be needed to clarify it. 


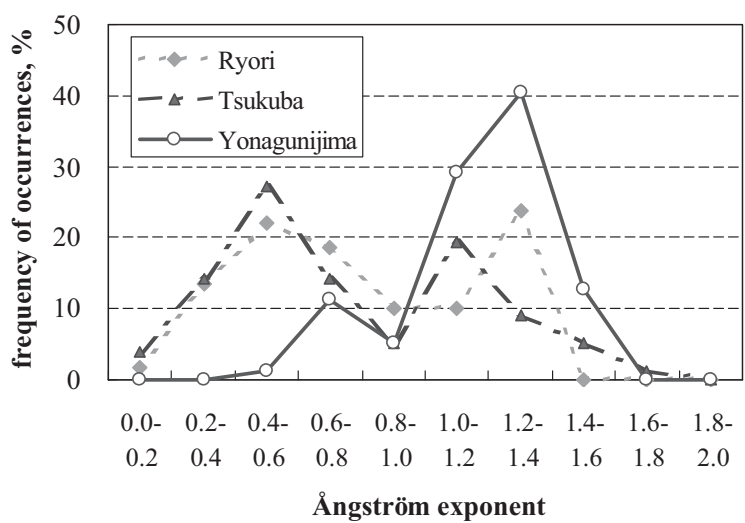

Fig. 4. Frequency of occurrence distributions for hourly mean Ångström exponent at Ryori (closed diamond), Tsukuba (closed triangle), and Yonagunijima (open circle) for $\tau_{500}>0.3$ during March-April 2002.

Table 1. Monthly mean $\tau_{500}$ and Angström exponents $(\alpha)$ with standard deviations during March-April 2002.

\begin{tabular}{l|c|c|} 
& mean $\tau_{500}$ & mean $\alpha$ \\
\hline Ryori & $0.28 \pm 0.19$ & $0.99 \pm 0.45$ \\
Tsukuba & $0.31 \pm 0.17$ & $0.94 \pm 0.37$ \\
Yonagunijima & $0.35 \pm 0.24$ & $1.10 \pm 0.27$ \\
Minamitorishima & $0.16 \pm 0.07$ & $0.60 \pm 0.25$
\end{tabular}

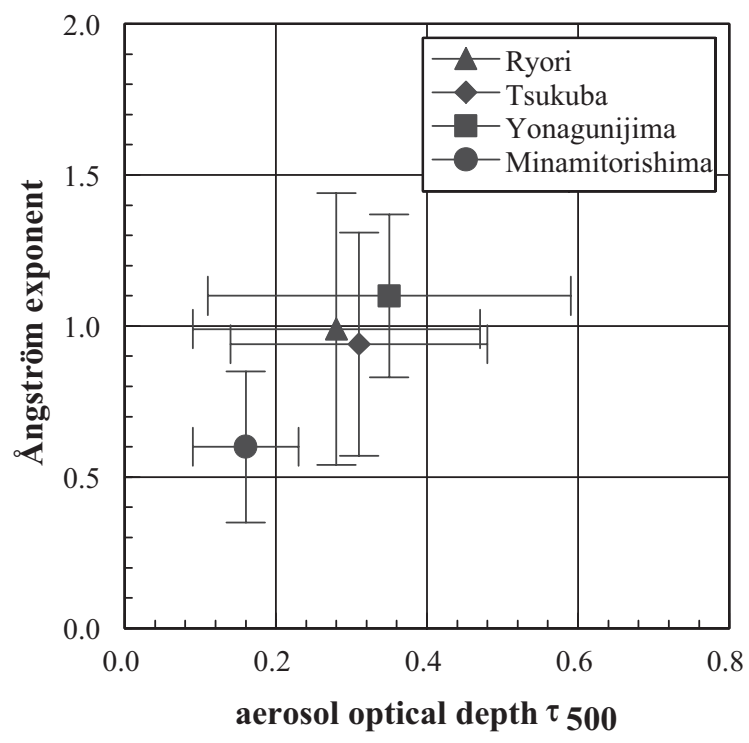

Fig. 5. Scatter plots of mean $\tau_{500}$ versus $\alpha$ with standard deviations during March-April 2002.

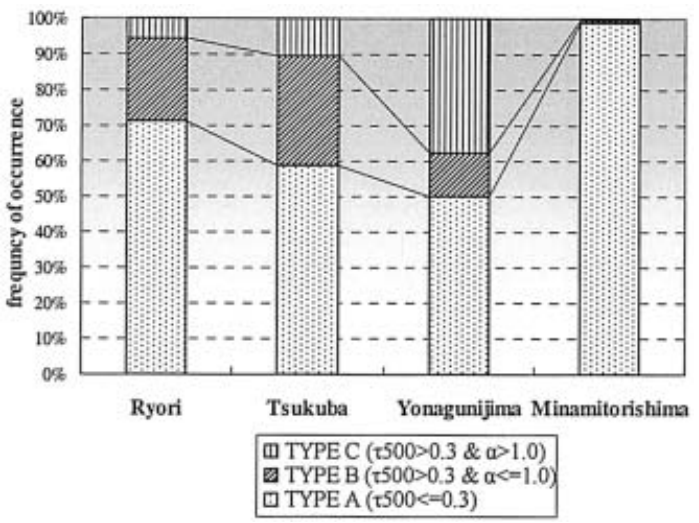

Fig. 6. Frequency of occurrence of event types recorded at observation sites during March-April 2002.

The frequency of Type $\mathrm{C}$ events (haze) in Ryori and Tsukuba was 5 and $11 \%$, respectively. For $\tau_{500}>0.3$, the frequency of occurrence of large- $\alpha(>1.0)$ events in Ryori and Tsukuba was also above $30 \%$ (Fig. 4). Haze events may not be uncommon in central and northern Japan.

Simulations by Takemura et al. (2003) showed that aerosol optical depths caused by aerosols formed from anthropogenic pollution in East Asia could exceed 0.3 over Japan in April 2001. Thus, the frequency of Type C events in Ryori and Tsukuba corroborate their results: the significant influence of springtime haze, in central and northern Japan, induced by anthropogenic aerosols. Indeed, a Type C event occurred on April 6, 2002, and the JMA lidar recorded a dense aerosol layer the $6 \mathrm{~km}$ above Ryori at a wavelength of $532 \mathrm{~nm}$ on that day. The backward trajectory from this aerosol layer passed over Nanjing $\left(32^{\circ} \mathrm{N}, 119^{\circ} \mathrm{E}\right)$. The chemical weather map by Sudo et al. (2002) shows that enhanced CO was transported from the east coast of the Asian continent to Japan at 6-km level (http://www.jamstec.go.jp/frsgc/ gcwm/index_j.html), which is consistent with the aerosol event observed. During the observation period, most of the daily backward trajectories at the 2-km level from Ryori (89\%) passed over East Asia or Northeast China. Thus, anthropogenic pollution in East Asia may be responsible for springtime haze events in central and northern Japan. 
Type $\mathrm{C}$ events in Tsukuba may be due to urban pollution in Tsukuba city (population about 150,000) or from the Tokyo Metropolitan area (roughly $50 \mathrm{~km}$ from Tsukuba). Indeed, relatively high concentrations of monthly-mean suspended particle matter $\left(0.030 \mathrm{mg} / \mathrm{m}^{3}\right.$ in March and $0.035 \mathrm{mg} / \mathrm{m}^{3}$ in April) were observed in Tsukuba in spring 2002 (http://www.nies. go.jp/igreen/index.html).

We have focused on haze events originating from anthropogenic pollution, however, in certain cases, it is hard to exclude boreal forest fires in Siberia as a possible cause. On April 13, 2002, Type $\mathrm{C}$ events were observed in Ryori, and the JMA lidar detected a dense aerosol layer at the $4-\mathrm{km}$ level. The chemical weather map at the 4-km level illustrates that the Asian pollution had not yet reached northern Japan at this time, but that a slightly enhanced CO layer extending from the north covered Ryori. The backward trajectory at the 4-km level from Ryori did not pass over any pollution region, and was traced back to the southwest of Lake Baikal $\left(50^{\circ} \mathrm{N}, 105^{\circ} \mathrm{E}\right)$ where major burning occurs in spring (Kajii et al. 2002). Boreal forest fires occur every year from April to October in Siberia and the Russian Far East, while the scale may differ (Kajii et al. 2002; Wotawa et al. 2001). The biomass burning in the Siberian Boreal forest might also account for a portion of the haze observed in northern Japan.

\subsection{Minamitorishima}

Minamitorishima is a remote island with a total coastline of only $5.5 \mathrm{~km}$. Clean oceanic conditions prevail on the island. The mean $\tau_{500}$ observed at Minamitorishima (Table 1) was larger than those obtained under similar clean oceanic conditions in the eastern Pacific during the spring (0.11-0.13) by Holben et al. (2001). Crawford et al. (1997) have reported large-scale pollution in the central western Pacific caused by the Asian outflow in the spring. Indeed, by the aircraft measurement over the western $\mathrm{Pa}$ cific in January, Zaizen et al. (1996) observed enhanced concentrations of mineral particles in the area, more than $2,000 \mathrm{~km}$ away from the Asian continent $\left(20-40^{\circ} \mathrm{N}, 140^{\circ} \mathrm{E}\right)$. From the daily trajectory analysis at the 2 -km level from Minamitorishima, $31 \%$ of trajectories were traced back to the Asian continent in March and April 2002. The relatively large $\tau_{500}$ in
Minamitorishima compared with those in the eastern Pacific is believed to be due to the springtime Asian outflow, which includes atmospheric pollution and mineral particles. The Asian outflow may have an affect on atmospheric optical properties in the spring more than $3,000 \mathrm{~km}$ away from the Asian continent, under the prevailing westerlies.

\subsection{Yonagunijima}

Among our four observation sites, the mean $\tau_{500}$ and a recorded in Yonagunijima were the largest (Fig. 5). As illustrated in Fig. 6, the frequency of Type $\mathrm{C}$ events (38\%) in Yonagunijima was significantly higher than at the other three sites. Moreover, in Yonagunijima, the frequency of large- $\alpha(>1.0)$ events was much higher than that of small- $\alpha(<1.0)$ events for $\tau_{500}>0.3$ (Fig. 4). Large values of $\alpha$ suggest a haze from biomass burning and/or urban pollution, as discussed in Section 3.1. The backward trajectory analysis at the $2-\mathrm{km}$ level from Yonagunijima shows that $43 \%$ of the daily trajectories passed over Southeast Asia, or coastal areas in Southeast China, during the observation period. Southeast Asia is known to be an area of frequent biomass burning in the spring; Liu et al. (1999) and Chan et al. (2003) have illustrated the geographical distributions of fires in this region. In addition, local pollution occurs around large urban cities along coastal areas in Southeast China (Chan and Chan 2000). Sunphotometry observation cannot distinguish between aerosol particles from urban pollution and smoke particles from biomass burning. Hence, it is thought that the haze from biomass burning in Southeast Asia, and/or urban pollution in coastal areas in Southeast China, are responsible for the relatively frequent occurrence of Type $\mathrm{C}$ events in Yonagunijima, examined as a case study in Section 4.2.

\section{Case studies}

4.1 A case study of severe Kosa events in Ryori Severe Kosa events, with a $\tau_{500}$ of around 1.0 and an $\alpha$ of less than 0.1 , were observed at Ryori on April 10, 2002 (data group labeled "I" in Fig. 3(a)). The JMA lidar in Ryori detected a Kosa layer below $2 \mathrm{~km}$, with a high backscattering ratio of above 5, and depolarization of above $20 \%$ on April 10, 2002. The isentropic backward trajectory analysis on the Kosa 

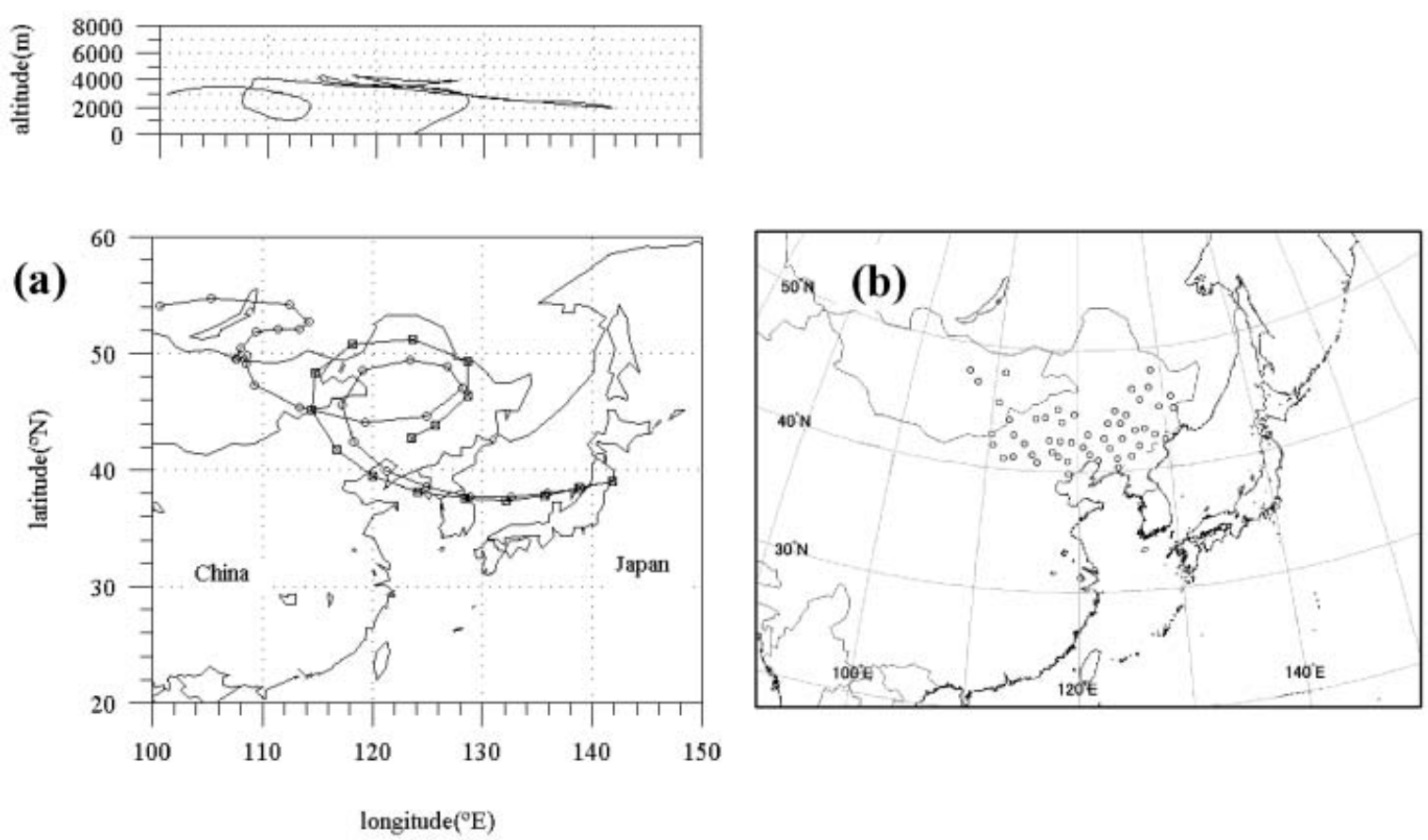

Fig. 7. Seven-day backward trajectories from Ryori at the 2-km level (a) and a map of meteorological stations that reported a surface dust event on April 7, 2002 (b). The trajectories begin to trace back at 0000 UT (thin line with rectangles) and 0600 UT (thin line with circles) on April 10, 2002. Symbols on the trajectories represent trajectory positions at 6 -h increments. The trajectory from 0000 UT over Ryori terminates at 0600 UT on April 6, 2002, because of contact with the surface.

event was performed from the observed Kosa layer over Ryori (Fig. 7). The backward trajectories from the Kosa layer over Ryori passed Northeast China $\left(44-50^{\circ} \mathrm{N}, 120-130^{\circ} \mathrm{E}\right)$ on April 7, 2002. According to the SYNOP present weather report from meteorological stations (ww $=06-09,30-35$, and 98; phenomenon corresponding to the code number is referenced in http://www.weather.org.uk/resource/wwcode. $\mathrm{htm}$ ), surface dust phenomena occurred in Northeast China on this day (Fig. 7). However, the occurrence of dust storms in this region was seldom before 2000 , and was unique to the 2000-2002 period (Kurosaki and Mikami 2003). Thus, this Kosa event reported in Northeast China was one instance of what has become a characteristic occurrence in recent years. In this case, a cyclone that had an occluded front in Northeast China $\left(45^{\circ} \mathrm{N}, 120^{\circ} \mathrm{E}\right)$ on April 7 , 2002 , might have caused the dust storm. Sugimoto et al. (2003) simulated this dust event by a chemical transport model. Their results support the close link between the dust storm and this cyclone. In Northwestern China, a specific meteorological analysis on dust storms was conducted by Gao et al. (2002). However, there are no such studies on Northeast China. Meteorological conditions that lead to the rise or transport of dust particles in Northeast China may need to be studied.

\subsection{A case study of haze events in Yonagunijima}

Severe Type C events with large $\tau_{500}(0.7-$ $0.9)$, and large $\alpha(1.2-1.4)$, were observed on April 7-8 in Yonagunijima (data group labeled "II" in Fig. 3(c)). As illustrated in the backward trajectory analysis (Fig. 8), the air masses below the $5-\mathrm{km}$ level over Yonagunijima came from Southeast Asia. The horizontal distribution of aerosol index (Herman et al. 1997), from the Earth Probe TOMS, shows a large area with high aerosol index $(>2.7)$ in Southeast Asia and the southern coast of the Asian continent on April 6-7, 2002 (http://toms.gsfc.nasa. gov/aerosols/aerosols.html), indicating the oc- 

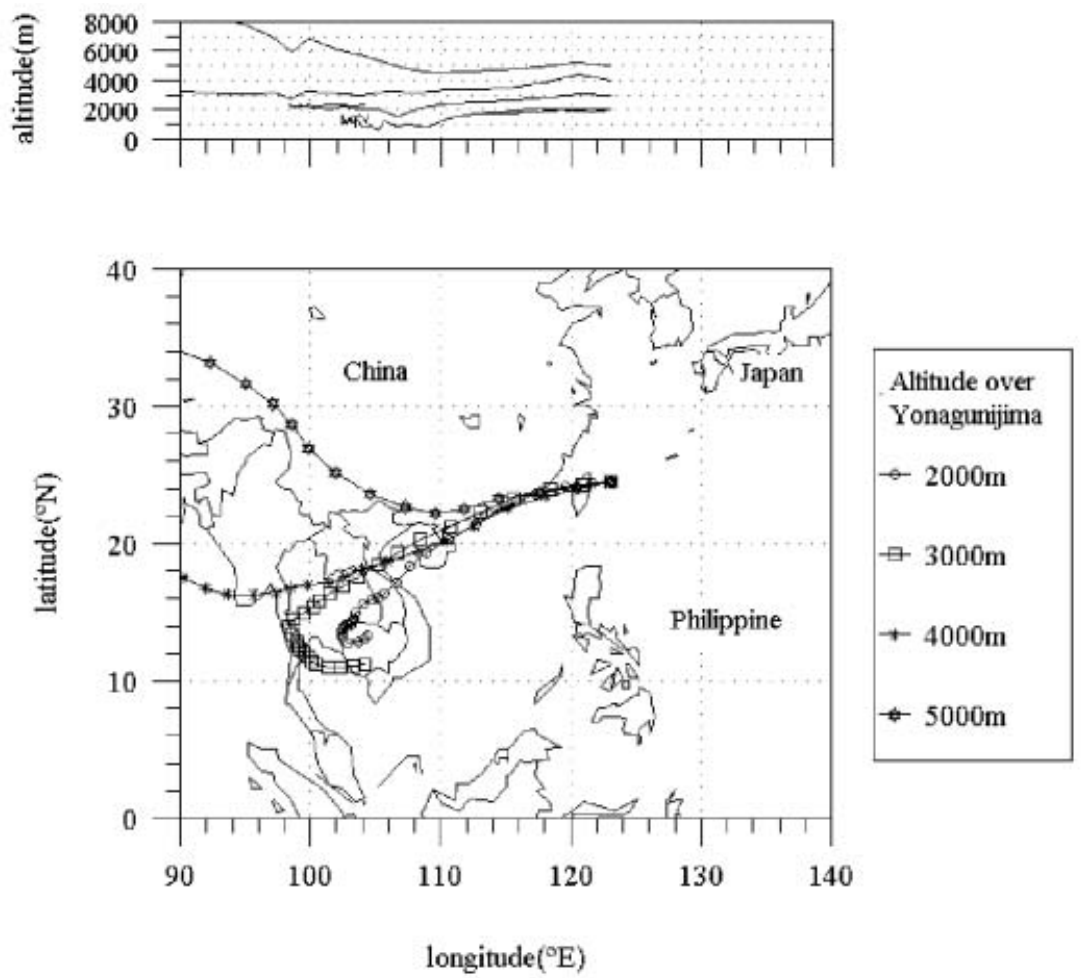

Fig. 8. Seven-day backward trajectories from Yonagunijima at 4 different altitudes. The trajectories begin to trace back at 0000 UT on April 7, 2002. Symbols show trajectory positions at 6-h increments.

currence of intense biomass burning in this region. The severe Type $\mathrm{C}$ events observed at Yonagunijima can be considered as one of the typical cases of smoke transports from Southeast Asia in the lower atmospheric layer, like Chan et al. (2003) pointed out. However, the trajectories that passed Hong Kong and neighboring cities in Fig. 8 also implicate urban pollution transport by the Asian outflow. The severe Type $\mathrm{C}$ events, observed on April 7-8 in Yonagunijima, were a series of typical haze events originating from biomass burning in Southeast Asia, and/or urban pollution in coastal areas in Southeast China, as discussed in Section 3.4.

\section{Summary}

Atmospheric optical phenomena in Ryori, Tsukuba, Yonagunijima, and Minamitorishima were analyzed using sun photometers during the period March-April 2002. The aerosol events observed were classified as follows: rela- tively clear conditions (Type A), typical Kosa conditions (Type B), and haze conditions (Type C). Type A events may include weak or background Kosa conditions.

During the observation period, the frequency of Type B events in Ryori and Tsukuba was $23 \%$ and $31 \%$, respectively. This indicates that significant Kosa events may well occur in central and northern Japan in the spring. Unusually high temperatures and strong westerlies were observed in East Asia in March 2002. However, further investigation of the annual variation will be necessary to reveal the relationship between the anomalous weather conditions and the relatively frequent occurrence of Type B events in northern Japan. Trajectory analysis showed that the severe dust event observed in Ryori on April 10, 2002, passed over Northeast China, where dust storms rarely occurred before 2000. The meteorological conditions that raised dust particles in Northeast China were likely linked to the Kosa event in 
Ryori, but further analysis is needed to confirm it.

The smallest mean $\tau_{500}$ and $\alpha$ values were both observed in Minamitorishima. However, the mean $\tau_{500}$ in Minamitorishima was larger than that in the eastern Pacific in the spring, indicating that the influence of the Asian outflow reached $3,000 \mathrm{~km}$ away from the Asian continent.

Large- $\alpha(>1.0)$ events occurred at a rate of above $30 \%$ in Ryori and Tsukuba at large aerosol optical depths $\left(\tau_{500}>0.3\right)$. Takemura et al. (2003) pointed out that anthropogenic pollution influences the atmospheric optical depth over Japan, and our results showed that the frequency of occurrence was not low. As in the case of the East Asian influence, anthropogenic pollution in East Asia may be responsible for springtime haze events, even in central or northern Japan. Urban pollution emitted in Tsukuba, or transported from the Tokyo Metropolitan area, is also believed to cause Type $\mathrm{C}$ events in Tsukuba. However, the possibility of Type $\mathrm{C}$ events in northern Japan caused by the haze transported from boreal forest fires in $\mathrm{Si}$ beria cannot be excluded.

The largest mean $\tau_{500}$ with the largest mean $\alpha$ at Yonagunijima reflected the distinctive influence of haze in this region. This was corroborated by the high frequency of Type $\mathrm{C}$ events (38\%) and the frequent transport of air masses from Southeast Asia and coastal areas in Southeast China, where haze due, respectively, to biomass burnings and urban pollution is a frequent occurrence. Indeed, the air mass that brought about the aerosol events, with the large $\tau_{500}$ and large $\alpha$ at Yonagunijima on April 7-8, 2002, came from Southeast Asia by way of coastal areas in Southeast China.

In conclusion, springtime haze events were found to be relatively common, not only in southern Japan, but also in central and northern Japan, and along with Kosa events, may have an impact on atmospheric optical properties over Japan. Haze conditions that prevail in Japan in the spring cannot be overlooked, and should be further investigated in the future.

\section{Acknowledgements}

This study was conducted under the aeolian dust experiment on climate (ADEC) project that was financially supported by the Ministry of Education, Culture, Sports, Science and Technology. We are grateful for this opportunity. We also thank Mr. T. Ohno, Mr. K. Takeuchi, Mr. T. Aoyagi, Mr. T. Hashimoto, Mr. A. Kinoshita, Mr. T. Ishimizu, and other staff members of the Atmospheric Environment Division within the JMA who provided the lidar data in Ryori, the trajectory analysis data, and the surface meteorological reports. Finally, special thanks are extended to Mrs. S. Yamamoto who processed massive amounts of original binary data.

\section{References}

Ångström, A., 1961: Techniques of determining the turbidity of the atmosphere. Tellus, 13, 214223.

Aoki, K. and Y. Fujiyoshi, 2003: Sky radiometer measurements of aerosol optical properties over Sapporo, Japan. J. Meteor. Soc. Japan, 81, 493-513.

Arao, K. and Y. Ishizaka, 1986: Volume and mass of yellow sand dust in the air over Japan as estimated from atmospheric turbidity. J. Meteor. Soc. Japan, 64, 79-94.

Chan, C.Y. and L.Y. Chan, 2000: Effect of meteorology and air pollutant transport on ozone episodes at a subtropical coastal Asian city, Hong Kong. J. Geophys. Res., 105, 20707-20724.

, J.M. Harris, S.J. Oltmans, D.R. Blake, Y. Qin, Y.G. Zheng, and X.D. Zheng, 2003: Characteristics of biomass burning emission sources, transport, and chemical speciation in enhanced springtime tropospheric ozone profile over Hong Kong. J. Geophys. Res., 108(D1), 4015, doi:10.1029/2001JD001555.

Crawford, J., D.D. Davis, G. Chen, J. Bradshaw, S. Sandholm, Y. Kondo, S. Liu, E. Browell, G. Gregory, B. Anderson, G. Sachse, J. Collins, J. Barrick, D. Blake, R. Talbot, and H. Singh, 1997: An assessment of ozone photochemistry in the extratropical western North Pacific: Impact of continental outflow during the late winter/early spring. J. Geophys. Res., 102, 28469-28487.

Eck, T.F., B.N. Holben, J.S. Reid, O. Dubovik, A. Smirnov, N.T. O'Neill, I. Slutsker, and S. Kinne, 1999: Wavelength dependence of the optical depth of biomass burning, urban, and desert dust aerosol. J. Geophys. Res., 104, 31333-31349.

Gao, X., S. Yabuki, Q. Zhang, and Q. Zhenan, 2002: Some characteristics of dust storm in Northwest China. J. Arid Land Studies, 11, 235243. 
Gregory, G.L., J.T. Merrill, M.C. Shipham, D.R. Blake, G.W. Sachse, and H.B. Singh, 1997: Chemical characteristics of tropospheric air over the Pacific Ocean as measured during PEM-West B: Relationship to Asian outflow and trajectory history. J. Geophys. Res., 102, 28275-28285.

Herman, J.R., P.K. Bhartia, O. Torres, C. Hsu, C. Seftor, and E. Celarier, 1997: Global distributions of UV-absorbing aerosols from Nimbus 7/TOMS data. J. Geophys. Res., 102, 1691116922.

Holben, B.N., D. Tanre, A. Smirnov, T.F. Eck, I. Slutsker, N. Abuhassan, W.W. Newcomb, J.S. Schafer, B. Chatenet, F. Lavenu, Y.J. Kaufman, J. Vande Castle, A. Setzer, B. Markham, D. Clark, R. Frouin, R. Halthore, A. Karneli, N.T. O’Neill, C. Pietras, R.T. Pinker, K. Voss, and G. Zibordi, 2001: An emerging groundbased aerosol climatology: Aerosol optical depth from AERONET. J. Geophys. Res., 106, 12067-12097.

Husar, R.B., D.M. Tratt, B.A. Schichtel, S.R. Falke, F. Li, D. Jaffe, S. Gassó, T. Gill, N.S. Laulainen, F. Lu, M.C. Reheis, Y. Chun, D. Westphal, B.N. Holben, C. Gueymard, I. McKendry, N. Kuring, G.C. Feldman, C. McClain, R.J. Frouin, J. Merrill, D. DuBois, F. Vignola, T. Murayama, S. Nickovic, W.E. Wilson, K. Sassen, N. Sugimoto, and W.C. Malm, 2001: Asian dust events of April 1998. J. Geophys. Res., 106, 18317-18330.

Iwasaka, Y., M. Yamato, R. Imasu, and A. Ono, 1988: Transport of Asian dust (Kosa) particles; importance of weak KOSA events on the geochemical cycle of soil particles. Tellus, 40B, 494-503.

Jaffe, D.A., T. Anderson, D. Covert, R. Kotchenruther, B. Trost, J. Danielson, W. Simpson, T. Berntsen, S. Karlsdottir, D. Blake, J. Harris, G. Carmichael, and I. Uno, 1999: Transport of Asian Air Pollution to North America. Geophys. Res. Lett., 26, 711-714.

Japan Meteorological Agency, 2002a: Monthly Report on Climate System, March 2002, Tokyo, 46p (in Japanese).

—, 2002b: Monthly Report on Climate System, April 2002, Tokyo, 46p (in Japanese).

- 2003: Annual report on atmospheric and marine environment monitoring, No. 3, March 2003 (CD-ROM) (in Japanese with English summary).

Kai, K., X.-N. Xiong, and A. Koshiba, 1998: Geographical distribution and long-rang transport of dust storms in the East Asia. J. Arid Land Studies, 8, 173-176 (in Japanese).

Kajii, Y., S. Kato, D. Streets, N.Y. Tsai, A. Shvi- denko, S. Nilsson, I. McCallum, N.P. Minko, N. Abushenko, D. Altyntsev, and T. Khodzer, 2002: Boreal forest fires i Siberia in 1998: Estimation and area burned and emissions of pollutants by advanced very high resolution radiometer satellite data. J. Geophys. Res., 107(D24), 4745, doi:10.1029/2001JD001078.

Kasischke, E.S. and L.P. Bruhwiler, 2003: Emission of carbon dioxide, carbon monoxide, and methane from boreal forest fires in 1998. J. Geophys. Res., 108, 8146, doi:10.1029/ 2001JD000461.

Kurosaki, Y. and M. Mikami, 2002: Seasonal and regional characteristics of dust event in the Taklimakan desert. J. Arid Land Studies, 11, 245-252.

$\longrightarrow$ and -2003 : Recent frequent dust events and their relation to surface wind in East Asia. Geophys. Res. Lett., 30, 14, 1736, doi:10.1029/2003GL017261.

Liu, H., W.L. Chang, S.J. Oltmans, L.Y. Chan, and J.M. Harris, 1999: On springtime high ozone events in the lower troposphere from Southeast Asian biomass burning. Atmos. Environ., 33, 2403-2410.

McKendry, I.G., J.P. Hacker, R. Stull, S. Sakiyama, D. Mignacca, and K. Reid, 2001: Long-range transport of Asian dust to the Lower Fraser Valley, British Columbia, Canada. J. Geophys. Res., 106, 18361-18370.

Matsuki, A., Y. Iwasaka, D. Trochkine, D. Osada, and T. Sakai, 2002: Horizontal mass flux of mineral dust over east Asia in Spring: aircraftborne measurements over Japan. J. Arid Land Studies, 11, 337-345.

, K. Osada, K. Matsunaga, M. Kido, Y. Inomata, D. Trochkine, C. Nishita, T. Nezuka, T. Sakai, D. Zhang, and S. Kwon, 2003: Seasonal dependence of the long-range transport and vertical distribution of free tropospheric aerosols over east Asia: On the basis of aircraft and lidar measurements and isentropic trajectory analysis. J. Geophys. Res., 108, 8663, doi:10.1029/2002JD003266.

Mikami, M., O. Abe, M. Du, O. Chiba, K. Fujita, M. Hayashi, Y. Iwasaka, K. Kai, K. Masuda, T. Nagai, T. Ootomo, J. Suzuki, A. Uchiyama, S. Yabuki, Y. Yamada, M. Yasui, G. Shi, X. Zhang, Z. Shen, W. Wei, and J. Zhou, 2002: The impact of aeolian dust on climate: SinoJapanese cooperative project ADEC. J. Arid Land Studies, 11, 211-222.

Mizuno, T. and H. Kondo, 1992: Generation of local front and high levels of air pollution on the Kanto plain in early winter. Atmos. Environ., 26A, 137-143.

Moulin, C., F. Dulac, C.E. Lambert, P. Chazette, I. 
Jankowiak, B. Chatenet, and F. Lavenu, 1997: Long-term daily monitoring of Saharan dust load over ocean using Meteosat ISCCP-B2 data 2. Accuracy of the method and validation using Sun photometer measurements. J. Geophys. Res., 102, 16959-16969.

Murayama, T., N. Sugimoto, I. Uno, K. Kinosita, K. Aoki, N. Hagiwara, Z. Lin, I. Matsui, T. Sakai, T. Shibata, K. Arao, B.-J. Sohn, J.-G. Won, S.-C. Yoon, T. LI, J. Zhou, H. Hu, M. Abo, K. Iokibe, R. Koga, and Y. Iwasaka, 2001: Ground-based network observation of Asian dust events of April 1998 in east Asia. J. Geophys. Res., 106(D16), 18345-18359.

Smirnov, A., B.N. Holben, Y.J. Kaufman, O. Dubovik, T.F. Eck, I. Slutsker, C. Pietras, and R.N. Halthore, 2002: Optical properties of atmospheric aerosol in maritime environments. $J$. Atmos. Sci., 59, 501-523.

Sudo, K., M. Takahashi, J. Kurokawa, and H. Akimoto, 2002: CHASER: A global chemical model of the troposphere, 1 . Model description. $J$. Geophys. Res., 107(D17), 4339, doi:10.1029/ 2001JD001113.

Sugimoto, N., I. Uno, M. Nishikawa, A. Shimizu, I. Matsui, X. Dong, Y. Chen, and H. Quan, 2003; Record heavy Asian dust in Beijing in 2002: Observations and model analysis of recent events. Geophys. Res. Lett., 30, 12, 1640, doi:10.1029/2002GL016349.

Suzuki, K., O. Uchino, M. Yoshida, K. Honda, M. Aono, F. Watanabe, and T. Ootomo, 2001: Kosa (yellow sand) events in April, 1998 and 1999 observed by sunphotometers. Tenki, 48, 317322 (in Japanese).

Takenmura, T., I. Uno, T. Nakajima, A. Higurashi, and I. Sano, 2002: Modeling study of longrange transport of Asian dust and anthropogenic aerosols from East Asia. Geophys. Res. Lett., 29, 24, 2158, doi:10.1029/2002GL016251. , T. Nakajima, A. Higurashi, S. Ohta, and N. Sugimoto, 2003: Aerosol distributions and radiative forcing over the Asian Pacific region simulated by Spectral Radiation-Transport Model for Aerosol Species (SPRINTARS).
J. Geophys. Res., 108, 8659, 10.1029/ 2002JD003210.

Talbot, F.W., J.E. Dibb, B.L. Lefer, J.D. Bradshaw, S.T. Sandholm, D.R. Blake, N.J. Blake, G.W. Sachse, J.E. Collins, Jr., B.G. Heikes, J.T. Merrill, G.L. Gregory, B.E. Anderson, H.B. Singh, D.C. Thorton, A.R. Bandy, and R.F. Pueschel, 1997: Chemical characteristics of continental outflow from Asia to the troposphere over the western Pacific Ocean during February-March 1994: Results from PEMWest B. J. Geophys. Res., 102, 28255-28274.

Tanaka, M., M. Shiobara, T. Nakajima, M. Yamano, and K. Arao, 1989: Aerosol optical characteristics in the yellow sand events observed in May, 1982 at Nagasaki-part 1 observations. $J$. Meteor. Soc. Japan, 67, 267-278.

Tanimoto, H., Y. Kajii, J. Hirokawa, H. Akimoto, and N.P. Minko, 2000: The atmospheric impact of boreal forest fires in far eastern Siberia on the seasonal variation of carbon monoxide: Observations at Rishiri, A northern remote island in Japan. Geophys. Res. Lett., 27, 4073-4076.

Uno, I., H. Amano, S. Emori, K. Kinoshita, I. Matsui, and N. Sugimoto, 2001: Trans-Pacific yellow sand transport observed in April 1998: A numerical simulation. J. Geophys. Res., 106, 18331-18344.

Wotawa, G., P.C. Novelli, M. Trainer, and C. Granier, 2001: Inter-annual variability of summertime $\mathrm{CO}$ concentrations in the Northern Hemisphere explained by boreal forest fires in North America and Russia. Geophys. Res. Lett., 28, 4575-4578.

Xiao, H., G.R. Carmichael, J.D. Durchenwald, D. Thornton, and A. Bandy, 1997: Long-range transport of SOx and dust in East Asia during the PEM B Experiment. J. Geophys. Res., 102, 28589-28612.

Zaizen, Y., M. Ikegami, Y. Tsutsumi, Y. Okada, J. Jensen, and J.L. Gras, 1996: Number concentration and size distribution of aerosol particles in the middle troposphere over the western Pacific Ocean. Atmos. Environ., 30, 1755-1762. 